\title{
OBITUARY.
}

\section{Wheelton Hind, M.D., B.S., F.R.C.S., F.G.S.}

BonN 1860.

DIED JUNE 21, 1920.

Dr. Wheelton Hind was born at Roxeth, near Harrow, in 1860, and died after a comparatively short illness at Ashley, near Stokeon-Trent, on June 21 of this year. He received his medical training at Guy's Hospital and London University, where he graduated M.D., and also gained the Fellowship of the Royal College of Surgeons. In 1884 he began practice in Stoke-on-Trent, and during the following thirty years established a reputation as one of the foremost surgeons in the district, being at the time of his death the senior member of the surgical staff of the North Staffordshire Infirmary.

So far as research work is concerned, Hind's interest in geology practically dates from his arrival in Stoke, for very shortly thereafter he made the first of a long series of contributions on local geology to the Transactions of the North Staffordshire Naturalists' Field Club. Amongst his earliest papers was one on the geology of Suffolk, which was incorporated in his father's book on the flora of that county. As might be expected from his location in a coal-mining district, most of his work related to the stratigraphy and palæontology of the Carboniferous rocks, especially of the lower members of that series. In an endeavour to find some key to the succession of these strata he soon extended his investigations to the corresponding rocks of Derbyshire, Lancashire, and Yorkshire, where he collaborated with Mr. J. A. Howe in a detailed examination of the Lower. Carboniferous sequence of the Pendle Hill area. As a result of this work the hitherto recognized classification of this series underwent considerable modification by the recognition of the "Pendleside Series" of shales and thin limestones, with a characteristic fauna, as a group intermediate between the Carboniferous Limestone and the Millstone Grit and differing essentially, both in lithology and fossils, from the Yoredale Series. The development of this series in Derbyshire and Staffordshire was recognized, and it was also traced to the Isle of Man and Ireland.

The basis of Hind's stratigraphical work was the attempt to discover a series of life-zones by means of which the Carboniferous rocks could be subdivided and those in different districts correlated. For several years he acted as secretary of the British Association Committee on "Life-zones in the British Carboniferous Rocks", and not only collected assiduously himself but also identified much of the material obtained by others. The comparative lack of success in this work, so far as the Carboniferous Limestone is concerned, was possibly due to the fact that most of the collecting was done in the North Midland area, where continuous sequences are conspicuously absent. Even the results of Vaughan's brilliant researches 
in the Bristol district have not been found easy of application to the northern series, although much of Hind's subsequent work was directed towards that end.

By the discovery of Pendleside zone-fossils in the Culm measures of Devonshire, Hind was able to show that the lower portion of the latter was homotaxially equivalent to the former, while the goniatite fauna of the higher Culm strata confirms Arber's conclusion that they are of Middle Coal-measures age. Despite military duties entailed by the War-Hind went to France as Lieut.-Colonel in command of the North Midland Territorial R.G.A., and later occupied responsible hospital posts in various districts-he found time to elaborate the series of goniatite zones, ranging from the Posidonomya Becheri zone of the Pendleside up to the Middle Coal-measures, which he had formulated in 1909, and, in conjunction with Dr. A. Wilmore, to apply them in a detailed re-examination of the Clitheroe district.

At an early stage in his work he recognized the necessity for a reinvestigation of the Carboniferous mollusca, and the fruits of this appeared in the form of three monographs on the lamellibranchs. In conjunction with Mr. J. T. Stobbs a chart was drawn up in which these fossils, especially the freshwater species, were utilized in the establishment of horizons in the North Staffordshire Coalfield. Hind also published an important paper on the molluscan fauna of the Scottish Millstone Grit, and recognized the relationship to the fauna of homotaxially higher beds in America and Russia. His most important palæontological work relating to rocks other than the Carboniferous was his description of the Silurian Lamellibranchs in Mrs. Gray's Girvan collection.

Elected a member of the Geological Society of London in 1891, he received the Lyell award in 1902 and the Lyell medal in 1917. He was also an honorary member of the Société Géologique de Belgique, as well as of several British Societies. When it is remembered that his geological work was done in such time as could be snatched from a busy professional life, one marvels that so much was achieved. In a period of thirty years, some four of which were spent on war service, his published papers numbered over eighty, while in addition his services in the identification of fossils were largely utilized by the Geological Survey as well as by private workers. Such an output was only rendered possible by his wonderful vigour and enthusiasm. Whatever the verdict of the future regarding the details of his work, Hind will be remembered as one of the pioneers in the elucidation of the relationships of the Carboniferous rocks.

A. S.

1889. "The Natural Features and Geology of Suffolk": in W. M. Hind, Flora of Suffolk.

"Notes on some interesting Geological Sections in North Staffordshire": Trans. N. Staffs. Field Club, vol. xxiii, p. 77.

"A Description of an Inlier of Carboniferous Limestone at Birchwood Moor": ibid., pp. 441-6. 
1890. "Notes on the Curious Appearance produced by the Natural Bisection of some Spherical Concretions in a Yoredale Sandstone Quarry" Proc. Geol. Assoc., vol. xi pp. 424-7.

With J. Ward and others. "Excursion to North Staffordshire": ibid., pp. 117-36.

1891. "The Geology of Whitmore" : Trans. N. Staffs. Field Club, vol.xxv, p. 40.

"Notes on a Pre-Glacial River-bed at Stoke Road, Shelton": ibid., p. 53.

1893. "Description of a Slab from the Shale above the Kinder Scout Grit, Rabchester, Lancashire": GeoL. MAG., Ser. III, Vol. X, p. 540.

"Additions to the Palæontology of North Staffordshire": Trans. N. Staffs. Field Club, vol. xxvii, p. 103.

"The Affinities of Anthracoptera and Anthracomya": Quart. Journ. Geol. Soc., vol. xlix, pp. 249-75.

1894. With Sir.J. W. Dawson. "Note on the genus Naiadile:, as occurring in the Coal Formation of Nova Scotia": ibid., vol. l, pp. 435-42.

Presidential Address: Trans. N. Staffs. Field Club, rol. xxriii, pp. 1-21.

"A Monograph on Carbonicola, Anthracomya, and Naiadites" (Part I): Palæont. Soc., vol. x'viii, pp. 1-81, pls. i-xi.

1895. "A Monograph on Curbonicola, Anthracomya, and Naiadites" (Part II) : ibid., vol xlix, pp. 81-170, pls. xii-xx.

"The Chalk Flints of North Staffordshire": Colliery Guardian, vol. lxx, p. 1038.

1896. With F. Barke. "The Boulder Drift in North Staffordshire" : ibid., vol. lxxi, p. 461.

"On Zonal Divisions in the Carboniferous System": Geol. Mag., Dec. IV, Vol. III, pp. 255-61.

"A Monograph on Carbonicola, Anthracomya, and Naiadites" (Part III) : Palæont. Soc., vol. l, pp. 171-82, pl. xxi.

"A Monograph of the British Carboniferous Lamellibranchiata" (Part I) : ibid., pp. 1-80, pls. i-ii.

1897. "A Monograph of the British Carboniferous Lamellibranchiata" (Part II): ihid., vol. li, pp. 81-208, pls. iii-xv.

"Section in Carboniferous Limestone Shales at Tissington, on the New Buxton and Ashbourne Railway": Trans. N. Staffs. Field Club, vol. xxxi, pp. 115-17.

"On the Subdivision of the Carboniferous Series in Great Britain and the True Position of the Beds mapped as the Yoredale Series": Geol. Mag., Dec. IV, Vol. IV, pp. 159-69, 205-13.

1898. "The Life-zones of the Carboniferous Defosits of Europe": ibid., Dec. IV, Vol. V, pp. 61-9.

"A Monograph on the British Carboniferous Lamellibranchiata" (Part III) : Palæont. Soc., vol. lii, pp. 209-76, pls. xvi-xıv.

"The Yoredale Series": Colliery Guardian, vol. 1xxvi, pp. 709-10, $757-8$.

" On Mr. W. Gunn's Correlation of the Carboniferous Rocks of England and Scotland": ibid., pp. 506-8.

1899. With others. "Life-zones in the Britist Carboniferous Rocks" : ibid., vol. lxxviii, pp. 702-4. Report Brit. Assoc. for 1898, p. 529.

"The Subdivision of the Carboniferous Series in Great Britain and some of their European Equivalents": Trans. Edinburgh Geol. Soc., vol. vii, pp. $33 \geq-60$.

"What are the Real Equivalents of the Yoredale Rocks of Wensleydale in the Midlands?": Trans. N. Staffs. Field Club, vol. xxxiii, p. 67.

"On the Correlation of British and European Carboniferous Beds": Trans. Manchester Geol. Soc., i ol. xxvi, Fp. 96-112.

" On Three New Species of Lamellibranchiata from the Carboriferous Rocks of Great Britain": Quart. Journ. Geol. Soc,, vol. Iv, pp. $365-70$. 
With W. Gibson. "The Agglomerates and Tuffs of Congleton Edge" : ibid., pp. 548-59.

"On the Occurrence in British Carboniferous Rocks of the Devonian genus Palceoneilo, with a description of New Species": Proc. Geol. Soc., pp. 18-19; Quart. Journ. Geol. Soc., vol. Ivi, pp. 46-9. 1900.

"A Monograph of the British Carboniferous Lamellibranchiata" (Part IV): Palæont Soc., vol. liii, pp. 27i-360, pls, xxvi-xxxix.

With H. A. Bemrose. "Long Excursion to Derbyshire": Proc. Geol. Assoc., vol. xvi, pp. 221-5.

1900. "A Monograph of the British Carboniferous Lamellikranchiata" (Part V) : ibid., rol. liv, pp. 361-476, pls. xl-liv.

"Scaldia minuta": Trans. N. Staffs. Field Club, vol. xxxiv, pp. 93-4.

"Report on Carboniferous Rocks and Fossils, South Pennine District": Report Brit. Assoc. for 1899, pp. 371-5.

1901. "Life-zones in the British Carboniferous Rocks": ibid, for 1900 pp. 340-2.

With J. A. Howe. "The Geological Succession and Palæontology of the Beds between the Millstone Grit and the Limestone Massif at Pendle Hill and their Equivalents in certain other parts of Britain ": Quart. Journ. Geol. Soo., vol. lvii, pp. 347-404.

"A Monograph of the British Carbonjferous Lamellibranchiata" (Vol. II, Part I) : Palæont. Soc., vol. lv, pp. 1-34, pls. i-vi.

"The Carboniferous Limestone of Lilleshall": Trans. N. Staffs. Field Club, vol. $x \times x v$, pp. 1-3

1902. "A List of Localities where Fossils occur in the Pendleside Series of the Country round North Staffordshire": ibid., vol. xxxvi, pp. $77-80$.

"On the Characters of the Carboniferous Rocks of the Pennine System": Proc. Yorks Geol. Soc., vol. xiv, pp. 422-64.

"The Sequence of the Carboniferous Rocks in North Staffordshire": Trans. Inst. Min. Eng, vol, xxii, pp. 219-27.

The Geology of Staffordshire.

Review of The Geology of the Country around Stoke-on-Trent (Mem. Geol. Surv.): GeOL. MAG., Dee. IV, Vol. IX, pp. 563-7.

"The Life-zones of the British Carboniferous Rocks": Rep. Brit. Assoc. for 1901, pp. 288-96

1903. Ditto: ibid, for 1902, pp. 210-16.

"On a New Species of Solenopsis from the Pendleside Series of Hodder Place, Stoneyhurst": Quart. Journ. Geol. Soc., vol. lix, pp. 334-6.

"Notes on some Lamellibranchiata obtained by Mr. A. J. C. Molyneux from the Sengwe Coalfield": ibid., p. 287.

"Notes on some Dictyonema-like Organisms from the Pendleside Series of Pendle Hill and Poolvash ": Proc. Geol. Soc., p. 80.

And others. "Whitsuntide Excursion to North Staffordshire": Proc. Geol. Assoc., vol. xviii, pp. 173-84.

And J. T. Stobbs. "Chart of Fossil Shells found in connection with Seams of Coal and Ironstone in North Staffordshire" : Newcastleunder-Iyme.

"A Monograph of the British Carboniferous Jamellibranchiata" (Vol. II, Part II) : Palæont. Soc, vol. lvii, pp. 35-124, pls. vii-xxi.

1904. Ditto (Vol. II, Part III) : ibid., vol. lviii, pp. 125-216, pls. xxij-xxv.

"On the Homotaxial Equivalents of the Lower Culm of North Deronshire": Geol. MaG., Dec. V, Vol. I, pp. 392-403, 526, $584-7$.

"Life-zones in British Carboniferous Rocks": Rep. Brit. Assoc. for 1903 , pp. 185-92.

1905. Ditto: ibid., for 1904, pp. 226-37.

"On the Beds which succeed the Carboniferous Limestone in the West of Ireland": Proc. Roy. Irish Acad., vol. xxvb, pp. 93-116. 
"Notes on the Palæontology of the Marine Beds in the Coal.measures of North Staffordshire": Quart. Journ. Geol. Soc., vol. Ixi, pp. 527-46.

Review of Geology of Derby, etc. (Mem. Geol. Surv.): Geol. MaG., Dec. V, Vol. II, p. 547.

1906. "Note on the Characters of the Hinge-plate in Aviculopecten semi. costatus" : ibid., Dec. V, Vol. III, p. 59.

With J. T. Stobbs. "The Carboniferous Succession below the Coalmeasures in North Shropshire, Derbyshire, and Flintshire" : ibid., pp. 385-400, 445-59, 496-507.

"Fossil Molluscan Zones in the Carboniferous Rocks of the Midlands," part i : The Naturalist, pp. 253-6.

"Life-zones in the British Carboniferous Rocks"': Rep. Brit. Assoe. for 1905 . pp. 171-4.

1907. Ditto : ibid., for 1906 , pp. 302-13.

"Speculations on the Evolution of the River Trent": Trans. $N$. Staffs. Field Club, vol. xli, pp. 93-100.

"Fossil Molluscan Zones in the Carboniferous Rocks of the Midlands," part ii : The Naturalist, pp. 17-26, 90-6.

"The Palæontological Succession of the Carboniferous Rocks in the South of the Isle of Man": Proc. Yorks. Geol. Soc., vol. xvi, pp. $137-54$.

" On the Occurrence of Dendroid Graptolites in British Carboniferous Rocks": ibid., pp. 155-7.

1908. "Life-zones in the Britjsh Carboniferous Rocks": Rep. Brit. Assoc. for 1907, pp. 316-17.

1909. "Description of Two New Species of Lamellibranchs from Marine Bands of the Yorkshire Coalfield ": Proc. Yorks. Geol.Soc., vol, xvi, pp. 335-6.

" Lillieshall Hill" : Trans. N. Staffs. Field Club, vol. xliii, pp. 112-15.

"Present State of our Knowledge of Carboniferous Geology" : The Naturalis*, pp. 149-56, 163-70, 228-9, 245-51.

"The Homotaxial Equivalents of the Culm of Western Germany" : Geol. Mag., Dec. V, Vol. VI, pp. 468-72.

" On the Lamellibranch and Gasteropod Fauna of the Millstone Grit of Scotland": Trans. Roy. Soc. Edinburgh, vol. xlvi, pp. 331-59.

1910. "The Lamellibranchs of the Silurian Rocks of Girvan" : ibid, rol. xlvii, pp. 479-548.

"Correlation of the Yoredale and Pendleside Series" : The Naturalist, pp. 307-10.

"Staffordshire" : Geol. Assoc. Jubilee Vol., pp. 564-91.

1911. "Four new Carboniferous Nautiloids and a Goniatite new to Great Britain" : Proc. York: Geol. Soc., vol. xvii, pp. 97-109.

1912. "Les Faunes Conchyliologiques du Terrain Houiller de la Belgique" : Mem. Mus. R. Hist. Nat. Belg., vol. vi, pp. 1-18.

1914 "Temnocheilud derbiensis, sp. nov." : Proc. Yorks Geol. Soc., vol, xix pp. 18-19.

"Palreontological Notes on the Millstone Grit Beds between Masham and Great Whernside" : ibid., vol. xix, pp. 25-34.

1918. "The Distribution of the British Carboniferous Goniatites": Geot. Mag., Dec. VI, Vol. V, pp. 434-50.

"The Caninia-seminula Horizon of Productus humerosus": ibid., p. 480.

1919. With A. Wilmore. "The Carboniferous Succession of the Clitheroe Province" : Proc. Geol. Soc.; to be published in extenso in Proc. Yorks Geol. Soc.

1920. With F. Barke and A. Scott. "A Quartzose Conglomerate at Caldon Low, Staffordshire" : Geol. Mag., Vol. LVII, pp. 76-32.

"The Distribution of the British Carboniferous Nautiloids" : ibid., pp. 405-11. 